\title{
THE POEM AS A WHOLE: TRANSLATING Chris MCCully's ICARUS AND HOUSES ${ }^{1}$
}

\author{
O POEMA COMO UM TODO: TRADUZINDO \\ ICARus e Houses de Chris Mccully
}

\author{
Santiago Quiroz Pardo \\ University of Essex \\ Colchester, Essex - United Kingdom \\ ORCID 0000-0002-6378-4776
}

\begin{abstract}
This article presents translations from English into Spanish for Icarus and Houses, two poems from Chris McCully's Selected Poems (2011), along with a critical commentary. I discuss the controversial topic of poetic translation and some of the most relevant theoretical issues related to it, including the dichotomy of originality and equivalence, the usefulness of framing the endeavour within the principle of equivalence effect, the importance of treating the poem as an organic whole, and the benefit of considering different forms of intertextuality during the translation process. Using Robert Bly's Eight stages of Translation (1982) as a methodological guideline, I discuss some of the decisions that led to the final Spanish version of the poems. I conclude that translation, even beyond poetry, should be framed as a creative act rather than a passive rendering of what has already been said.
\end{abstract}

Keywords: poetic translation; equivalence effect; intertextuality; Chris McCully.

\section{Resumo}

Este artigo apresenta traduçóes do inglês para o espanhol de Icarus e Houses, dois poemas de Selected Poems (2011) de Chris McCully, junto com um comentário crítico. Discuto o tema controverso da tradução poética e algumas das questóes teóricas mais relevantes relacionadas a ele, incluindo a

\section{Resumen}

Este artículo presenta traducciones del inglés al español de Icarus y Houses, dos poemas tomados de Selected Poems, de Chris McCully (2011), acompañadas de un comentario crítico. Discuto acerca de la traducción poética, tema controversial, y acerca de algunas de las cuestiones teóricas más relevantes,

1 This article is based on my MA dissertation, titled "A creative act: Translating from Chris McCully's Selected Poems", completed at the University of Essex. I would like to thank my supervisor, Lexa Olivera Smith, for her helpful comments and guidance. I also wish to thank Chris McCully, for giving me permission to use his poetry for my dissertation and for the valuable insight he provided during our interviews. Thanks to Carcanet Press for allowing me to use the poems 
dicotomia de originalidade e equivalência, a utilidade de enquadrar o esforço dentro do princípio de equivalência do efeito, a importância de tratar o poema como um todo orgânico, o benefício de considerar diferentes formas de intertextualidade durante o processo de traduçáo. Utilizando Oito estágios de tradução (Eight stages of Translation) (1982) de Robert Bly como uma diretriz metodológica, discuto algumas das decisōes que levaram à versão final em espanhol dos poemas. Eu concluo que a tradução, mesmo além da poesia, deve ser enquadrada como um ato criativo, em vez de uma cópia passiva do que já foi dito.

Palavras-chave: tradução poética; equivalência do efeito; intertextualidade; Chris McCully. como la dicotomía entre originalidad y equivalencia, la utilidad de enmarcar esta tarea dentro del principio de efecto de equivalencia, la importancia de tratar el poema como un todo orgánico y la ventaja de considerar distintas formas de intertextualidad durante el proceso de traducción. Tomando las Ocho etapas de la traducción (Eight stages of Translation) de Robert Bly (1982) como guía metodológica, discuto algunas de las decisiones que llevaron a la versión final de los poemas. Concluyo que la traducción, incluso por fuera de la esfera poética, debería considerarse un acto creativo y no una copia pasiva de lo que ya se ha dicho.

Palabras clave: traducción poética; efecto de equivalencia; intertextualidad; Chris McCully.

This article summarizes a larger project where I explored poetic translation. This is a controversial topic, as some believe the translation of poetry is an impossible task. Roman Jakobson (2000, p. 118) saw it as an exception to his belief that everything was translatable: "poetry by definition is untranslatable. Only creative transposition is possible".

This view is understandable. All elements at all levels of a poem - sound, rhythm, meter, imagery, tone, connotations, denotations, and any other - are part of its integrity. All of them can contribute to the aesthetic effect and polysemy of the piece, and it is impossible to preserve all of them in translation. Furthermore, if we follow Coleridge's famous definition of poetry as "the best words in the best order", then we must agree that it is impossible to render such a text in a different language, as the very nature of translating poetry is replacing those best words and changing that best order.

Some, however, reject this idea. Octavio Paz (1971, p. 11), for example, highlights the universality of poetry and points at translation as the essence of language and as an act of literary trans- 
formation (1971, p. 9-10). Others, like Eliot Weinberger, go even further: "Great poetry lives in a state of perpetual transformation, perpetual translation: the poem dies when it has no place to go" (WEINBERGER; PAZ, 1987, p. 1). In this view, poetry is not only translatable, but demands to be translated.

Perhaps the key to unravelling this debate is to examine what we mean by "translation". It is true that the target texts will never be exactly the source text. However, this is not exclusive to the translation of poetry. As Peter Robinson (2010, p. 173) states: “[...] no translation can be such reproduction [...] Once this is accepted, then it becomes possible to see how poetry like everything else, is translatable, if that word is understood to mean a remaking in the other terms of a different structure of materials". This is a far more useful approach to translation, and it is in this sense that poetry can be considered translatable.

Such an act of creation was what I endeavoured to carry out in my translation project, which presented Spanish translations for a number of English poems, all taken from Chris McCully's Selected Poems (2011), along with a critical commentary. In this article, I discuss some of the most relevant theoretical issues considered therein, as well as two practical examples with their respective commentary.

\section{Originality and equivalence in poetic translation}

We must first ask what poetic translation entails. From this issue arises the question of equivalence and originality: to what degree should the target text be equivalent to the original - and what can 'equivalence' mean for the translation of poetry? Also, to what degree should the resulting work be treated as an original?

According to Jackson Mathews (1959, p. 67), “ [...] to translate a poem whole is to compose another poem. A whole translation will be faithful to the matter, and it will 'approximate the form,' of the original; and it will have a life of its own, which is the voice of the translator". This statement gives a special status to both the translation and the translator. However, to a certain degree, Mathews still considers equivalence - or, as he calls it, faithfulness -, as a rubric for assessment of the poem. 
How should the translation be faithful, then? "Deciding to translate a poem is, at the start, a matter of perceiving what the translator hopes to be faithful to" (MATHEWS, 1959, p. 67). How we judge equivalence, then, depends on the approach the translator has taken. In regards to the 'approximation of form' Mathews states: "the motive is invention, not imitation. The translator has to invent formal effects in his own language that give a sense of those produced by the original on its own" (1969, p. 67). According to this approach, the final goal of the translation of poetry is to create a new poem with new formal effects, but those should reflect the original, finding a new way of arriving at the same destination.

Within translation studies, this is reminiscent of Nida's 'equivalence effect.' Nida (2000, p. 129) distinguishes between 'formal equivalence,' where "the message in the receptor language should match as closely as possible the different elements in the source language" and dynamic equivalence, which "aims at complete naturalness of expression, and tries to relate the receptor to modes of behaviour relevant within the context of his own culture" (2000, p. 129). While this can be correlated to foreignization and domestication, Nida adds an extra layer to his conception of dynamic equivalence by making it depend on the principle of equivalence effect: "that the relationship between receptor and message should be substantially the same as that which existed between the original receptors and the message" (2000, p. 129). With this in mind, a translation of poetry is perhaps best assessed by asking whether it achieves the same poetic effects as the original, even if it does so through different means.

Fortunately, the dilemma between equivalence and originality becomes undone once we consider it in regards to Robinson's framing of translation as a creative act. In this view there is no contradiction between a poem being new and being faithful, between the invention of new poetic effects and the resemblance to the original ones. Instead, it is a matter of remaking. In other words, while a translator of poetry must be aware that their translation is a new poem, they must also remember that they are attempting to capture a previous poem. For this reason, my translation project sought to create Spanish poetry that, inevitably, were new works of poetry, whi- 
le at the same time being attempts to capture the English originals, focusing on achieving equivalence effect.

\section{The poem as an organic whole}

We must now consider the specifics of Mathews's faithfulness. What may the translator decide to preserve? The problem is that a poem is not a series of features that we can separate from each other. Bassnett (1991, p. 82), talking about some methods of translation described by Lefevere in Translating Poetry (1975), warns that "[...] deficiencies of the methods [...] are due to an overemphasis on one or more elements of the poem at the expense of the whole". We must remember that a poem is indivisible, and the new poem must be too. In the target text some features may resemble the original more than others, but if the poem is truly alive, then the new features that have occupied the place of the ones we have lost must also incorporate to the whole in an organic way.

Remembering that different features of a poem are all connected was vital for my translation project, and I endeavoured to consider those connections when translating and when assessing translations. However, it is possible to discuss elements of these features separately for the benefit of clarity. Therefore, the commentary considers specific elements while taking into account their interconnectivity.

\section{Bly's stages of translation}

A useful methodology to approach the translation of a poem as a whole is Robert Bly's (1982) eight stages of translation. This method is useful in two ways. First, the steps focus on different aspects of the poem, thus assuring that the translator will take several elements into consideration, without overemphasizing one over the others. This brings the poem closer to an integral whole. Of course, it does not include every single feature of a poem, but it does take into account several vital ones.

Second, these steps are not meant to be sequential: "[...] the stages will often collapse into each other, or a single line will suddenly 
go through all eight stages in a flash, while the other lines lie about looking even more resistant than before" (BLY, 1982, p. 68). This assures us that we are not translating the several aspects of the poem as independent parts, but that we do consider them as one whole. The steps are as follows:

1. Writing a literal version of the poem in the target language: Bly highlights that our immediate reaction is "What happened to the poem? Where did it go?" (BLY, 1982, p. 69) What this means is that a mere literal translation will not be poetry.

2. Interpreting the poem: Here the translator must understand what the poem means. Bly recommends discussing it with someone else to really grasp all the meanings of the poem (BLY, 1982, p. 70). Personally, I had the opportunity to interview McCully and obtained certain clarifications from him. Of course, we must remember that the meanings of the poem are not independent from other features, and that poetry is polysemic.

3. Reworking the translation in the target language: The literal or word for word translation could hardly be considered to be in the target language, but merely a calque of the source language structure. On this stage, the objective is to render the target text in the structure of the target language. Bly expresses this in terms of energy, how sentences gain it with different structures. English, for instance gains energy "by embarking the main noun immediately and the verb soon after" (BLY, 1982, p. 73).

4. Translating the poem into a living spoken language: What this means is that, in order to be alive, the poem needs to be written not only in an abstract idea of the target language, but into a version of it that is actually spoken. "We need the energy of spoken language as we try to keep a translation alive, just as we need the energy of the written" (BLY, 1982, p. 75). In his example, Bly makes the example of translating it into American or British English. In our case, it is translating it into Latin American Spanish. He adds that great poets always "mingle spoken language and written language in the most delicate way; 
the poem balances informal tones and formal" (BLY, 1982, p. 75). However, it is important to remember that "the aim is not street language, not slang as such [...] but rather the desperate living tone or fragrance that tells you a person now alive could have said that phrase" (BLY, 1982, p. 75). This stage requires listening to the poem.

5. Attempting a version that preserves the tone or mood of the poem: In this stage the translator must feel and reproduce the tone of the original in the target text. Landers (2001, p. 68) defines tone as "[...] the overall feeling conveyed by an utterance, a passage, or an entire work, including both conscious and unconscious resonance". Moreover, he points out that sometimes tone can change within a single work.

6. Focusing on capturing the sonority of the poem: In this stage, the focus is on sound. Bly distinguishes between two types of sonority. The first one refers to the rhythm of the poem, its beats, the strength of each syllable and the feeling of motion that one gets from the sonority of the verse. For Bly, this is the focus of this stage. The second type of sonority, which he leaves somewhat vague, is "sound calling to sound, which is related to internal rhyme" (BLY, 1982, p. 83). We can consider it the sonority of repeating sounds, which includes rhyme, alliteration and similar devices. In regards to particular phonemes, Lefevere (1975, p. 19) considered phonemic translation, where the translator tries to replicate the phonemes of the source text. As he observes, those approaches tend to be a failure, barely readable constructions where the meaning and other elements have been distorted. It is pointless to try to replicate phonemes. However, I will personally admit to enjoying when similar phonemes appear in the target text as in the source text, with the caveat that what is important is the equivalence effect that at times is obtained through phonemes of similar weight.

7. Asking for help: Bly recommends asking a native speaker of the source language for help, to see if there is an important detail in the original that has been lost. However, I believe a critical reader of poems in the target text may be 
even more important, in order to make sure that the poem work as a poem.

8. Making the final draft: Bly includes in this stage the possibility of reading other translators' versions of the source text. This is not applicable to this project.

Bly's method highlights four characteristic that the target poem should have. The first has to do with the final translation in itself: it should use living spoken language. The other three are about equivalence: the target text should retain the meanings of the original, or at least the most important meanings, as the translator-poet must have properly interpreted the poem; it should be similar in tone, and it must have a similar or equivalent sonority. Of course, the target poem might not be exactly equivalent to the original in the same way across all these rubrics, and we must consider the poem as a whole, but they are still useful for assessing the translation's quality, in part because all of these elements contribute to the poetic effects the poem has on the reader, which means that they help achieve the desired equivalence effect. I considered all these aspects when carrying out my translation project, both during the translation and for the commentary.

\section{Intertextuality}

Poetry often includes references to other works, often other poems. This makes the subject of intertextuality an important topic for literary translation. Hatim and Mason (1990, p. 123) discard the reductive notion that "[...] intertextuality is some static property of texts, which in translating amounts to mere item-by-item replacement of a reference [...] on the contrary, intertextuality is best viewed in terms of semiotic systems of signification". Therefore, an occurrence of intertextuality in a work must be considered not only in terms of replacement, but in regards to the function that they serve, both for the inner coherence of the text and in terms of its relation to outside elements. Hatim and Mason point to a passive intertextuality which "amount to little more than the basic requirement that texts be internally coherent" (1990, p. 124), and to more active functions where texts depend "[...] on the prior existence, not only of clearly 
identifiable texts, but also of general conditions of appropriateness that may, for example, govern entire genres. Intertextuality in this sense makes it possible for us to situate a text in a system of relevant codes and conventions" (1990, p. 124-125). Thus, while they point to more noticeable forms of intertextuality like imitation, plagiarism, parody and citation, merely using a specific genre is an important act of intertextuality that must be considered in translation.

We can improve upon that last point by incorporating Genette's classic theory of intertextuality. Genette defines five different forms of transtextuality, of relationships between texts: intertextuality, defined as "co-presence between two or more texts [...] by the literal presence of one text within another"; paratextuality, which includes elements like titles, subtitles, forewords, and all other texts that are not part of the main text but frame it; metatextuality, which refers to the relationship between a commentary and "the text it comments upon (without necessarily citing it)"; hypertextuality which refers to "the superimposition of a later text on an earlier one that includes all forms of imitation, pastiche and parody", and architextuality, which refers to "the relationship of inclusion linking each text to the various kinds of discourse of which it is representative" (GENETTE apud MACKSEY, 1997, p. xviii-xix).

Considering different forms of transtextuality, such as intertextuality and architextuality, during the translation process can help produce a better translation by taking into account the different textual relationships that occur within a poem and between the poem and other texts. After all, the relationship between the original and the translation is itself a form of hypertextuality, an imitation in a different genre. I took care to achieve this in my translation project.

Having considered some of the most relevant theoretical issues and a useful methodology, I will now present two practical examples: McCully's original poems Icarus and Houses, accompanied by their Spanish translations, along with their respective commentaries. 


\section{Icarus $^{2}$}

\begin{tabular}{|c|c|}
\hline Icarus & Ícaro \\
\hline He was mad with it: & Deliraba con la idea: \\
\hline the intricacies of construction, & los ínfimos detalles de la construcción, \\
\hline the wax that sealed each joint & con la cera que sellaba cada eje \\
\hline to a workable point; & hasta hacerlo funcionar, \\
\hline the local clarities of angles, & con la claridad exacta de los ángulos, \\
\hline feathers; whatever could explain & las plumas; aquello, lo que fuera, \\
\hline the assemblage and harness it & que pudiera explicar el ensamblaje y enlazarlo \\
\hline to the dynamics of the sky. & a las dinámicas del cielo. \\
\hline He was mad with it, & Deliraba con la idea, \\
\hline and as the air glazed & y cuando el aire acariciaba suavemente \\
\hline without effort under the beating wings, & los contornos y el ritmo de las alas, \\
\hline as the olive groves and the blue zoo & cuando los campos de olivo \\
\hline of the sea receded merely & y el zoológico del mar se redujeron \\
\hline to hillsides and ocean, & a meras colinas y al océano, \\
\hline a disarticulated view, & una visión desarticulada, \\
\hline he had succeeded. & sintió su triunfo entre los aires. \\
\hline He was mad with it - & Deliraba con la idea, \\
\hline the whole beautiful engineering. & la belleza pura de la ingeniería. \\
\hline But turning westwards, higher, & Pero \\
\hline becoming pressure, becoming weight, & al virar hacia el oeste, más arriba, \\
\hline he had forgotten the sun. & al devenir \\
\hline And strange that when there was & presión y peso, \\
\hline that endless sense of falling, & se había olvidado del sol. \\
\hline he was glad of it. & Qué extraño, \\
\hline & cuando percibió \\
\hline & la infinita sensación de la caída, \\
\hline & la recibió con agrado. \\
\hline
\end{tabular}

2 Available at: <https://www.carcanet.co.uk/cgi-bin/indexer?product=9781847770189> 
As its title indicates, this poem is a retelling of the myth of Icarus. However, Daedalus is seemingly absent, making Icarus the apparent creator of the wings. The focus is now on his obsession with the "the intricacies of construction." It is therefore a work about obsessive creativity. It is tempting to define Icarus as a poem about writing poetry. However, it can apply to all sorts of artistic endeavours and acts of creativity.

The first line is crucial, as it opens every stanza, creating structure and rhythm for the poem as a whole, ending with the variation of the final line. It also demands a careful translation decision, as "He was mad with it" does not have an acceptable literal translation. To arrive at my solution I was inspired in part by Bly's sixth step, capturing the sonority of the poem.

First, in regards to rhythm, the original line gives the impression of rising motion, appropriate for a poem about Icarus: it goes toward the resounding, stressed word "mad", and then comes back down on "with it". I attempted to recapture this with "deliraba", where instead of rising towards a specific word it goes towards the stressed syllable /ra/ and begins descent in /ba/. As Spanish tends to use more and longer words, I had to make the line longer with "con la idea", but I managed to replicate the rising and falling motion, towards the stressed /de/ or allophone/ðe/ followed by unstressed /a/, the two syllables that close the line.

Second, there is the matter of individual phonemes. As I said before, phonemic translation is a foolish errand, but I do take pleasure in encountering such similarities in the translation, as long as they contribute to equivalence effect. This happened in that first line. An aesthetic rhythm occurs with the phonemes in "mad with it." The consonant sounds, /d/, / / and /t/, are phonetically similar, and the final vowels are both $/ \mathrm{I} /$. Additionally, the descending sounds after "mad" are softer, appropriate for this poem. While my translation does not have that kind of repetition, I do enjoy seeing the similarity between /de/ in "deliraba" and /de/ or allophone /ðe/ in "idea", which gives it the desired aesthetic rhythm.

More importantly, the presence of the phonemes /idea/ or allophone /iðea/, as in the original, make it a softer line than if I had just left "deliraba", which finishes with the rougher /ba/ sound. In 
other words, once I had written "con la idea", the softer sound of the final word provided the desired equivalence effect. And even though I do not believe in trying to preserve phonemes in translation, the certain phonemic similarities between the /wıðt/ of the original and the /idea/ -or /iðea/- of the translation do bring me some satisfaction. That said, it is important to remember that it would be wrong to assume that "idea" is the phonemic translation of "with it." Rather, idea appeared as the correct translation that satisfied the poetic equivalence effect on both a phonetic and semantic sense-which, as established before, should not be viewed as separate elements.

With this in mind, it is useful to discuss how the semantic aspect operates. Semantically, "deliraba" is a good equivalent for "mad with it", as it better conveys a continual - but not perpetual - state of obsession that can even be pleasurable, unlike other Spanish words in the semantic field of madness, such as those derived from "locura", which feel far more clinical.

However, what I really need to justify is "con la idea", which replaces the original "with it." What does the "it" in the original refer to? The poem presents a list of elements that make up the work that obsesses Icarus, summarizing it with "whatever could explain/the assemblage and harness it/ to the dynamics of the sky" in the first stanza and with "the whole beautiful engineering" in the second one. "It", then, refers to the entirety of the wings. Why "idea", then?

First, it fits well with the poem's focus on obsession. Its madness must be mental, and it must therefore be considered in the form of thoughts, i.e., ideas. Second, it fits with my interpretation of the poem. If it is about obsessive creation, then it is appropriate to express this in terms of ideas, of all the thoughts that arise and vanish during the creative process, the visions that guide the creation of a work and the flashes that touch it in only minuscule ways.

Third, "idea" works well with another aspect of the poem: the ineffability of Icarus' experience. The verse "whatever could explain [...]" suggests that there is a certain aspect to the work that Icarus cannot quite grasp, an element that allows the wings to rise and whose presence he is aware of, but can never truly name. I relate this to the inexpressible feeling of beauty or transcendence that one chases when engaging in creative work. I believe the non-materiality 
of "idea" does a good job in expressing that, as ideas are not docile entities. Rather, their non-materiality assures that humans never fully grasp them.

All of this made "Deliraba con la idea" a satisfying opening line, but this choice caused an issue with the structure of the poem, as it is meant to close with a variation: "he was glad of it." Before I arrived at a solution, I had to carefully interpret the function of the fall in the poem, so that I could arrive at a solution that was aesthetically, tonally and semantically satisfying. This meant translating the rest of the poem.

I relate the fall to the previously mentioned feeling of transcendence, which also influenced my translation for "whatever could explained" as "aquello, lo que fuera". This intends to convey how difficult it is to define or express such an experience. A part of it always remains undefinable.

However, despite its power, it is a state with limitations. Even if during the act of creation an artist believes or perceives themselves as reaching a higher state of awareness, it is only temporary. No matter how high an artist soars, they always fall back to earth, Icarus must always fall. And yet, the poem expresses beauty in the fall. Its tone is not despair. There is beauty in that fall. Icarus "was glad of it." Perhaps he understands the fall was inevitable, an inescapable part of the creation process that has lifted him towards the sun.

All of this influences the translation, especially in regards to tone, the preservation of which is Bly's fifth step. In the first part of the poem, it meant retaining the sense of beautiful obsession. On the second part, one must preserve the bliss of the flight and the peaceful nostalgia, the glad melancholy of the fall.

This led me to take several translation decisions. First, I tried to preserve the bliss before the fall by replacing "he had succeeded" with "sintió su triunfo entre los aires." It is a considerable departure from the original, but it was inspired, above all, by equivalence effect. The original line is soft, conveying the serenity of Icarus' glide. More literal translations like "había tenido éxito," would eliminate this. So would the resounding "sintió su triunfo" on its own, but it allowed for the serenity of the next words, the softer "entre los aires." I believe this achieves the desired effect. 
Then came the fall. I wanted to preserve the rhythm of the two lines "But turning westwards, higher/becoming pressure, becoming weight $[\ldots]$ " They stand out from the previous ones in that their commas seemingly breaks them in two pieces, while most of the previous lines presented uninterrupted, flowing segments. These commas in the final stanza give the fall a different, perhaps less flowing rhythm than that of the preceding flight ${ }^{3}$.

I attempted to cause a similar effect and emphasize the impression of falling by dividing the lines. The word "Pero" now noticeably separates the fall from the rest of the poem, and the shorter, more numerous lines give the almost graphic impression of falling, while capturing the change in rhythm in the original.

Tonally, this fall remains calm, especially as it approaches the final verses. I split the verses again in "qué extraño, / cuando percibió $[\ldots]$ ", as this continued the effect of the fall and emphasized the power of "la infinita sensación de la caída." Furthermore, the wondering "qué extrańo" gave the lines, in my view, a sense of contemplation that emphasized the peace felt by Icarus.

And so came the closing verse. I could not exactly replicate the exact effects of the original, where "he was glad of it" gives the sense of satisfied completion to the repeating "he was mad with it." However, there is no possible equivalent that could be a variation of "deliraba con la idea".

However, the resulting line itself, "la recibió con agrado", manages to preserve the desired peaceful tone, perhaps because Icarus ceases to be an active agent and simply receives the sense of falling, because the phonemes maintain the necessary softness -the original /glad/and the resulting /agrado/ are somewhat close- or simply because "agrado" is an emotion that does not call attention to itself. It does not have the energy or motion of those derived from "feliz" or "alegre". Instead it remains calmly pleased with itself. That is the tone I wanted to communicate in the final lines of the poem.

3 The only exception was the semicolon after "feathers", which also causes a noticeable break when reading the poem. However, this one works to separate the preceding list of concrete elements that obsess Icarus from the appositive "whatever could explain the assemblage," which, as mentioned before, is less clearly defined and more overtly difficult to express. 


\section{Houses $^{4}$}

\begin{tabular}{|c|c|}
\hline Houses & Casas \\
\hline They seem solid: render and Accrington brick; & Apariencia sólida, ladrillo revestido, buen color, \\
\hline Good lines; set angles on a suburb slope & Ángulos firmes, suburbio, y nadie alcanza \\
\hline Where no one hears (the walls are two feet thick) & A oír tras las paredes (medio metro de grosor) \\
\hline The neighbours loudly drinking down their hope. & Los vecinos que pasan con un trago su esperanza. \\
\hline But scaffolding's erected everywhere & Pero el andamiaje aún se erige en todas partes \\
\hline And yesterday these houses' roofs were gone; & Y ayer los techos de estas casas se habían ido; \\
\hline The day before, the stonework layer by layer & Un día antes, cada capa de piedra del baluarte \\
\hline Vanished into dance-hall whistling and the sun. & Se evaporó entre obreros, martillos y silbidos. \\
\hline Foundations turned to foot-prints, which grew back & Los cimientos volvieron a ser huellas; del camino, \\
\hline To moor and coppiced hazel; road bled a spring & Alivio de caballos, sangraba un manantial; \\
\hline Where horses drank; and through the Zodiac & El hilo zodiacal revertía su destino \\
\hline The past unravelled on its stick of string & Y el árbol de avellano crecía en el erial. \\
\hline Until what made the paid-for future there & Y al final aquel futuro cierto se deshizo \\
\hline Were merely geese and winter, sleet and air. & Dejando solo gansos, el invierno y el granizo. \\
\hline
\end{tabular}

Aesthetically, three things immediately stand out from Houses. First, it is a classic English sonnet, mostly in iambic pentameter and following ABAB-CDCD-EFEF-GG as a rhyme scheme. Second, enjambment is a lot more evident in the second half of the poem, starting with the one between lines 7 and 8 . Third is the strong sonority of the opening line, which rather than iambic pentameter is better scanned as a spondee, a troche, two dactyls and an extra stressed syllable:

\section{THEY SEEM/SO-lid/REND-der-and/AC-cring-ton/BRICK}

This strong sonority matches the solidity of the houses in question, as does the absence or invisibility of enjambment in the first half of the poem. It works well with the idea of strong, resistant and well defined constructions. When the houses and the landscape

4 Available at: <https://www.carcanet.co.uk/cgi-bin/indexer?product=9781847770189> 
become unfixed and lose their clear limits, so do the verses, thus the more apparent enjambment in the second half of the poem.

As for the use of the sonnet form, it is useful to remember the discussion on intertextuality in the literature review. There is a relationship between the poem and the kind of text that it is exemplifies, what Genette defined as architextuality. Therefore, the use of a sonnet connects us both to the idea of the sonnet and to all previous and future examples of the form. Therefore, when the reader encounters the poem and sees that it is a sonnet, it will trigger associations. The first one will be an awareness that this poem is written in the most classic of all English poetic forms, one that has been used since far into the past until today. Perhaps more strongly, the reader will remember that this was the form often used by the great poets of the Elizabethan era. The effect, hopefully, will be awareness that this form is an appropriate vehicle to travel back towards the past, towards a seemingly untouched natural landscape, as this poem does.

With this in mind, I endeavoured to preserve the form of a rhyming sonnet. Add to this the fact that very early on, I attempted non-rhyming versions, but they proved unsatisfactory. Therefore, these attempts no longer exist. Besides, shortly after beginning the translation, the idea arose of using "buen color" to rhyme with "grosor" and that "alcanza" rhymes with "esperanza." In other words, the poem started rhyming on its own.

Some of my first attempts with this poem tried to look for the equivalence effect by writing a classic Spanish sonnet, with an ABBA-ABBA-CDE-CDE (or, alternatively, CDE-DCE or CDC-D$\mathrm{CD}$ ) rhyme scheme, but I soon discarded that method, as I realized preserving the closing rhyming couplet was better for the poem.

I also attempted to use the more classic Spanish meter of the hendecasyllable as a fit for iambic pentameter, but the fact that Spanish words tend to be longer than English words meant that too much was lost by restricting syllable count. It is as Lefevere (1975) warns: such metrical translation "[...] soon reveals itself in practice as a very rigorous straitjacket imposed on the target text".

The final, hopefully successful version, is more liberal with meter, although little by little it became imperfect Spanish alexandrines. The alexandrine is a classic form in Spanish, but the alexandrine 
sonnet is more directly connected with modernism, à la Ruben Darío, rather than to the old classics. However, the alexandrine is still a medieval meter and a sonnet is still a sonnet, not to mention that the rhyme scheme shows the reader that the poem is an imitation of the English original sonnet, so the final form remains an appropriate vehicle for our travel into the past.

As the translation formed, the effect of the enjambment was lost. It is evident between lines 2 and 3 of the target text. I attempted to compensate this in two ways. First, besides rhyming, the lexical choice of "baluarte" and "erial" in the second half of the poem is meant to appear to the reader as words that belong more to the past than to the present, hopefully without being so outdated that they make the poem dead. Second, I originally used slightly more strange syntax that seemed more like a baroque poem, as in "el camino sangró para sed de los caballos manantial". However, I soon discarded that method, which made the poem awkward instead of reminiscent of Quevedo or Góngora. We may see this as Bly's third and fourth step, where the poem should be written not only in proper Spanish, but in the living language of Latin American Spanish, as opposed to trying to imitate some form of long-dead baroque.

On the subject of Bly, his sixth step of preserving sonority was also important. Notably, I attempted to capture the strong sonority of the first line by making the words heavy. "Accrington" was lost in the process, but the resulting line is strong enough for it to be an acceptable loss. In particular, "apariencia" is meant to be equivalent to the strong start of the spondee and the trochee in the original. Of course, the first two syllables are not stressed, but their phonemes, / apa/, have a strong sonority, especially when followed by the resounding /rjensja/, making it a suitable replacement.

Something else of note is that in the first two lines there is a stronger sense of a list of nominal clauses, unlike the original, which opens with a full sentence. The result is a sense of staccato which is meant to add to the solidity of the verses.

The desire to preserve sonority also led me to moving the verses in the second half so that the final syllables in lines 10 and 12 were stressed. This eliminates some of the enjambment, but it is both closer to the sonority that is felt at the end of the iambic pentameter 
lines in the original and a more graceful verse on its own. In the final version I also obtained an internal rhyme by changing "zodiaco" for "zodiacal."

Another notable change occurred in line 8, with "obreros, martillos y silbidos". This was the last change made to the poem, as the previous version read "se desvaneció en el sol y el son de cien silbidos". While perhaps closer to the original in that it keeps both the sun and whistling, it is also weaker, as "el son de cien silbidos", while keeping the rhythm, is more vague and less meaningful than the more specific "dance-hall whistling". The final result is instead based on a personal conversation with the author, where he told me he had written the line thinking of the workers that built the house, who would have attended the dance-hall and would therefore whistle the tunes they had heard there while working. We may relate this to Bly's seventh step. Some may criticize this, as the final result is based on outside information rather than the poem itself. However, even if it deviates from the original, I believe it ultimately achieves equivalence effect by presenting the reader with a concrete image of the house turning back in time, making it stronger and more meaningful.

Other, perhaps less interesting changes were inevitable. The past is no longer unravelling on a stick of string, instead the string of the zodiac is reversing its destiny. The journey to the past is simultaneous, rather than step by step. Air is absent from the final line. But the final result may stand as a poem on its own, one that manages to work as its own poem while at the same time being a translation of McCully's original.

\section{Conclusions}

Throughout this project I have attempted what many consider to be an impossible task: translating poetry. Whether I have achieved such a lofty objective depends on what one means by translation. If one sees translation as providing the same as in the source text but in a different language, then perhaps it truly is an impossible task: in all poems there were clear elements of difference, clear examples of deviation. The target texts are not exactly the source text. 
But then again, this is not exclusive to poetry. As Robinson (2010, p. 173) states: "The exact reproduction of the poetry of the original is strictly impossible [...] no translation can be such reproduction [...] this [...] doesn't set such a limit only to the translation of poetry, but to the translation of anything". If we instead conceive translation, as a "faithfully imitative approximation" (ROBINSON, 2010 , p. 32) that is still "creatively aware" (ROBINSON, 2010, p. 32), we may find the possibility of translating poetry, in both originality and equivalence.

This is a better conception of the activity of translation, even beyond poetry. Ours is a creative act, a remaking rather than a passive rendering of what has already been said. I believe I have shown this through my translation of Chris McCully's Selected Poems, and that I have produced works that are new poems while still being translations. Even when there has been loss, it has been for the sake of such an approach to translation, and, hopefully, for the betterment of the resulting poem.

In this activity of remaking I have followed Bly and I have attempted to make the poems be in the living and spoken Latin American Spanish, I have tried to retain meaning, tone and sonority, and I have tried to achieve an equivalent effect. I have also paid close attention to the workings of intertextuality and to the translation of culture-specific elements.

Still, the final test for any poem lies simply in its reading: as Mathews would put it: "The final test of a translated poem must be does it speak, does it sing? In spite of the restriction under which he works, in spite of his sense of fidelity to another poem, a translator is bound to sound out for himself" (1959: 68). I leave the final judgement to the reader.

\section{References}

BASSNETT, Susan. Translation Studies. Revised Edition. London: Routledge, 1991.

BLY, Robert. The Eight Stages of Translation. The Kenyon Review. n. 2, v. 4, Spring. 1982, p. 68-89. 
HATIM, Basil; MASON, Ian. Discourse and the Translator. New York: Longman, 1990.

JAKOBSON, Roman. On linguistic aspects of translation. In: VENUTI, L. The Translation Studies Reader. London: Routledge, 2000, p. 113118. [Original published in 1959].

LANDERS, Clifford. Literary Translation: a Practical Guide. Clevedon: Multilingual Matters, 2001.

LEFEVERE, André. Translating Poetry: Seven Strategies and a Blueprint. Assen: Van Gorcum, 1975.

MACKSEY, Richard. Foreword. In: GENETTE, G. Paratexts. Cambridge: Cambridge University Press, 1997, p. xii-xxiv.

MATHEWS, Jackson. Third Thoughts On Translating Poetry. In: BROWER, Reuben A. On Translation. Cambridge: Harvard University Press, 1959, p. 67-77.

MCCUlly, Chris. Selected Poems. Manchester: Carcanet Press, 2011. Available at <http://www.carcanet.co.uk/cgi-bin/indexer?product=9781847770189>. Accessed 28 August 2017.

NIDA, Eugene. Principles of Correspondence. In: VENUTI, L. The Translation Studies Reader. London: Routledge, 2000, p. 127-140. [Original published in 1964].

PAZ, Octavio. Traducción: literatura y literarlidad. Barcelona: Tusquets, 1971.

ROBINSON, Peter. Poetry \& Translation: The art of the impossible. Liverpool: Liverpool University Press, 2010.

WEINBERGER, E.; PAZ, O. Nineteen Was of Looking at Wang Wei: How a Chinese poem is translated. New York: Moyer Bell Limited, 1987.

Santiago Quiroz Pardo is a translator, literary researcher, and educator, currently independent. He recently graduated as a Master in Translation and Literature from the University of Essex (UK). He holds a BA in Literary Studies and a BA in Modern Languages from Pontificia Universidad Javeriana (Colombia). He has published poetry in Colchester-based Botch magazine and he has presented papers about Latin American literature and the works of Gabriel Garcia Marquez. E-mail: santiagoqu@gmail.com

Recebido em: 11/05/2018

Aceito em: 30/07/2018 